\title{
Upaya Meningkatkan Minat Untuk Menabung Pada PT. BPR Samudera Painan
}

\author{
Nuri Utama ${ }^{1)}$, Doni Marlius ${ }^{2)}$ \\ ${ }^{1,2)}$ Akademi Keuangan dan Perbankan Padang \\ nuriutama37@gmail.com
}

\begin{abstract}
The purpose of this study was to determine the efforts made at PT. BPR Samudera Painan in increasing custumer interest in saving. This research method is carried out in a qualitative way, namely explaning descriptively. Where the efforts made by PT. BPR Samudera Painan is conducting promotions by means of education, going to school, to majelis taklim, distributing, calendars, distributing brochures, placing advertisements through Painan radio with the aim of making prospective debtors aware of existing products and services and then relying on marketing patterns, namely savins services by picking up savings to a place customer businesses that received a positive response from custumers as seen by an increase in customer savings.
\end{abstract}

Keywords : Bank, Interest, Promotions

\section{PENDAHULUAN}

Sektor perbankan memiliki kedudukan sentral terhadap perekonomian di suatu negara. Hal tersebut dilihat dari peran strategis bank yaitu sebagai perantara keuangan. Akan tetapiperkembangan ekonomi berpengaruh besar terhadap kondisi global yang terjadi saat ini, seperti kondisi dunia sekarang yang sedang dilanda oleh wabah Covid-19 yang menyebabkan sebagian kegiatan masyarakat terhenti dan menurunnya pendapatan sehingga berdampak besar pada sektor perbankan. Akibat dari menurunnya sektor perekonomian tersebut, banyak masyarakat termasuk debitur bank yang kehilangan pekerjaannya, hal ini menyebabkan turunnya pendapatan sehingga debitur bank kesusahan untuk memenuhi kewajiban mereka kepada Bank.

Menurut Kasmir, (2014) Bank adalah lembaga keuangan yang menghimpun sejumlah dana dari masyarakat dalam bentuk simpanan, selain itu bank juga menyalurkan kembali kepada masyarakat dalam bentuk kredit adan bentuk lainnya guna meningkatkan taraf hidup masyarakat banyak.

Menurut Undang-Undang RI No. 10 Tahun 1998 Tentang Perubahan Atas UU No. 7 Tahun 1992 Tentang Perbankan Pasal 1 (2) : “ Bank merupakan badan usaha yang usaha utamanya menghimpun dana dan menyalurkan dana kembali kepada masyarakat dalam bentuk kredit atau bentuk lainnya guna untuk meningkatkan taraf hidup masyarakat". Sesuai dengan minat dari masyarakat banyak jenis bank yang bermunculan salah satunya Bank BPR. Menurut Herri, (2008) Bank Perkreditan Rakyat adalah suatu lembaga keuangan mikro di Indonesia yang mempunyai akar dalam sosial ekonomi masyarakat khusunya pedesaan Indonesia. 
Menurut Hary, (2014) Bank Perkreditan Rakyat merupakan jenis bank yang tugasnya untuk melayani golongan pengusaha mikro, kecil dan menengah sesuai dengan lokasi yang banyak dibutuhkan masyarakat. Sedangkan menurut Widayati, (2019) Bank Perkreditan Rakyat adalah lembaga keuangan bank yang tugasnya melakukan kegiatan usaha secara konvensional atau menggunakan prinsip syariah yang dalam kegiatannya tidak memberikan jasa dalam lalu lintas pembayaran. Bank Perkreditan Rakyat mempunyai ruang lingkup yang lebih kecil dibandingkan dengan bank umum sehingga Bank Perkreditan Rakyat hanya menerima simpanan dalam bentuk tabungan, deposito atau bentuk lainnya.

Berdasarkan Undang-Undang Nomor 10 Tahun 1998 Perubahan UndangUndang Nomor 7 Tahun 1992 tentang perbankan pasal 1 (9) Mendefinisikan bahwa : Pengertian Tabungan yaitu simpanan yang penarikannya hanya bisa dilakukan dengan syarat yang telah disepakati sebelumnya, namun tidak dapat ditarik menggunakan cek, bilyet giro, atau bentuk lainnya yang dipersamakan dengan itu. Menurut Widayati, (2019) Bank sebagai lembaga keuangan yang kegiatan pokoknya memberikan jasa penyimpanan dan menyalurkan dalam bentuk pinjaman kepada masyarakat serta mengutamakan pelayanan untuk memberikan kepuasan nasabah.

Kepuasan nasabah adalah perasaan nasabah setelah membandingkan antara apa yang diterima dengan harapannya Sondakh, (2015). Kepuasan nasabah dapat ditentukan dari kualitas produk yang ditawarkan dan pelayanan yang diberikan, sehingga jaminan dari kualitas produk merupakan suu hal yang paling diprioritaskan bagi pihak bank. Kualitas dan produk yang ditawarkan bank didapatkan dengan cara mencapai keinginan dan harapan nasabah, dengan meningkatkan nilai produk dan layanan agar memberikan nilai terbaik kepada nasabah apabila bank tersebut dapat memberikan manfaat, kualitas, dan pengorbanan seminimal mungkin Hidayat, (2009). Berbagai produk bank dibuat sesuai dengan kebutuhan nasabah serta kemudahan yang bertujuan untuk menarik minat masyarakat.

Minat merupakan suatu keinginan yang muncul dari diri sendiri tanpa adanya paksaan dari orang lain untuk mencapai suatu tujuan tertentu. Menurut Hidayat, (2009), minat adalah perasaan suka (senang) dan rasa tertarik dengan suatu objek atau kegiatan tanpa adanya unsur paksaan dari orang lain dan biasanya lebih memilih untuk mencari objek yang disukai tersebut. Seperti PT. Bank Perkreditan Rakyat Samudera Painan yang merupakan suatu lembaga keuangan dengan kegiatan simpan pinjam masyarakat dengan tujuan membantu masyarakat yang membutuhkan dana untuk usahanya ataupun untuk keperluan lainnya di daerah painan dan sekitarnya di kabupaten Pesisir Selatan. Namun akibat dari dampak Covid-19 maka PT. BPR Samudera Painan melakukan berbagai cara dalam meningkatkan minat masyarakat untuk menabung yaitu dengan memberikan kemudahan kepada masyarakat untuk menabung dan memberikan hal menarik lainnya, salah satunya dengan tabungan yang dijemput dirumah atau ditempat usaha nasabah setiap hari kerja yang dijemput oleh salah satu personil PT. BPR Samudera Painan. Berikut perkembangan jumlah tabungan pada PT. BPR Samudera Painan. 


\section{Tabel 1}

Laporan Rincian Posisi Simpanan PT. BPR Samudera Painan

Tahun 2015-2019

\begin{tabular}{ccc}
\hline Tahun & Jumlah rekening & Total tabungan \\
\hline 2015 & 4.858 & 3.839 .693 .217 \\
2016 & 6.110 & 2.409 .328 .957 \\
2017 & 6.713 & 2.744 .368 .144 \\
2018 & 7.587 & 3.457 .546 .000 \\
2019 & 5.615 & 4.589 .045 .750 \\
\hline
\end{tabular}

Sumber : PT. BPR Samudera Painan

Berdasarkan tabel diatas dapat dilihat bahwa jumlah tabungan pada PT. BPR Samudera Painan pada tahun 2015 dengan jumlah nasabah sebanyak 4.858 dengan total tabungan sebesar Rp. 3.839.693.217. dan pada tahun 2016 jumlah rekening pada PT. BPR Samudera Painan mengalami sedikit peningkatan dengan jumlah nasabah yaitu 6.110 dengan total tabungan sebesar Rp. 2.409.328.957. Pada tahun 2017 jumlah rekening yang ada pada PT. BPR Samudera Painan mengalami peningkatan dari tahun sebelumnya yang dapat dilihat dari jumlah nasabah nya sebanyak 6.713 dengan total tabungan sebesar Rp. 2.744.368.144. Pada tahun 2018 posisi simpanan pada PT. BPR Samudera Painan dengan jumlah nasabah sebanyak 7.587 mengalami peningkatan dari tahun sebelumnya dengan total tabungan sebesar Rp. 3.457.547.00. Dan pada tahun 2019 laporan posisi keuangan pada PT. BPR Samudera Painan mengalami penurunan dari tahun-tahun sebelumnya dapat dilihat dari jumlah nasabah sebanyak 5.615 sedangkan total tabungan sebesar Rp. 4.589.045.750.

\section{METODE PENELITIAN}

Di dalam penelitian ini penulis menggunakan metode pengumpulan data dengan dua cara yaitu :

1. Studi pustaka (library Research)

Penelitian ini dilakukan dengan cara mempelajari beberapa buku-buku ilmiah, artikel-artikel, bacaan laporan-laporan dan publikasi yang berhubungan dengan pembahasan yang dilakukan.

2. Studi Lapangan ( Field Research)

Penelitian dilakukan langsung di PT. BPR Samudera Painan untuk melengkapi data-data yang penulis butuhkan. Adapun cara riset lapangan adalah dengan langsung mewawancarai pihak yang bersangkutan dengan perusahaan atau instansi yang terkait.

\section{ANALISA DAN PEMBAHASAN Jenis-Jenis Bank}

Setiap bank dibedakan sesuai dengan jenis kebutuhan yang memiliki wewenang dan tugas masing-masing dalam melaksanakan kegiatannya.Jenis bank dibedakan menjadi 2 yang terdiri dari Bank umum dan Bank Perkreditan Rakyat (BPR), kedua bank mempunyai fungsi yang sama yaitu sebagai penghimpun dana dan penyalur dana kepada masyarakat. Dalam hal ini menunjukan bahwa bank berperan penting dalam perekonomian nasional karena fungsi bank dalam Pasal 1 
angka 2 UU perbankan mendefinisikan fungsi bank adalah badan usaha yang menghimpun dana dari masyarakat dalam bentuk simpanan dan menyalurkan kembali untuk masyarakat baik dalam bentuk kredit maupun dalam bentuk lainnya dalam rangka meningkatkan taraf hidup masyarakat.

\section{Fungsi Bank}

1. Menurut Widayati, (2019) fungsi bank seperti lembaga intermediasi dalam penyaluran dana berperan pentingsebagai penggerak roda perekonomian secara global dan memfasilitasi perkembangan ekonomi.

2. Secara umum fungsi utama bank adalah untuk menghimpun dana dari masyarakat dan menyalurkan kembali untuk masyarakat dengan tujuan untuk financial intermediary.

Sedangkan secara lebih spesifik bank berfungsi sebagai berikut:

a. Agent of Trust dasar utama aktivitas perbankan adalah kepercayaan, seperti pengumpulan dana dan penyaluran dana. Masyarakat yakin menitipkan dananya di bank apabila dilengkapi engan unsur kepercayaan

b. Agent of Development tugas bank untuk menghimpun dan menyalurkan dana sangat diperlukan demi kelancaran kegiatan perekonomian. Kegiatan bank tersebut mengizinkan masyarakat untuk melakukan investasi, distribusi dan juga konsumsi barang dan jasa, mengingat kegiatan investasi-distribusi-konsumsi berhubungan dengan penggunaan uang.

c. Agent of Service, selain kegiatan menghimpun dan menyalurkan dana, bank juga menawarkan jasa-jasa perbankan lainnya kepada rakyat. Jasa yang ditawarkan ini berhubungana dengan kegiatan perekonomian masyarakat secara umum

\section{Pengertian Bank Perkreditan Rakyat}

Bank Perkreditan Rakyat adalah lembaga keuangan mikro di Indonesia yang telah memiliki akar dalam perekonomian masyarakat pedesaan di Indonesia, BPR sebagai salah satu lembaga perbankan juga memiliki peranan yang penting dalam menunjang perekonomian di Indonesia Hejazziey, (2009).

Pengertian Bank Perkreditan Rakyat menurut Undang-Undang No.10 Tahun 1998 tentang perubahan Undang-Undang No.7 Tahun 1992 tentang Perbankan Pasal 1 (4) mendefinisikan bahwa : Bank Perkreditan Rakyat adalah bank yang menjalankan kegiatan usaha secara konvensional atau berdasarkan prinsip syariah yang dalam tugasnya tidak menyediakan jasa dalam lalu lintas pembayaran.

Menurut pasal 13 UU Perbankan No.10 tahun 1998 Bank Perkreditan Rakyat mempunyai suatu kegiatan usaha yaitu sebagai berikut :

a. Menghimpun dana dari masyarakat dalam bentuk simpanan seperti tabungan, deposito berjangka atau bentuk lainnya.

b. Memberikan kredit atau menyalurkan kembali pada masyarakat

c. Sebagai tempat penempatan dana dan pembiayaan berdasarkan prinsip syariah sesuai dengan ketentuan yang berlaku.

d. Menyimpan dananya dalam bentuk sertifikat Bank Indonesia (SBI), tabungan, sertifikat deposito, dan deposito berjangka 


\section{Asas, Fungsi, Tujuan dan Sasaran BPR}

Dalam menjalankan tugas dan usahanya BPR berasaskan demokrasi ekonomi dengan memakai prinsip kehati-hatian

Fungsi BPR yaitu lembaga keuangan yang kegiatan usahanya menghimpun dana dan menyalurkan kembali dana untuk masyarakat, tidak hanya sekedar menyalurkan kredit kepada para pengusaha mikro, kecil dan menengah, tetapi BPR juga menerima simpanan dari masyarakat

Tujuan BPR yaitu diarahkan dapat memenuhi kebutuhan jasa pelayanan perbankan bagi masyarakat pedesaan dan meningkatkan pertumbuhan ekonomi masyarakat dengan menyediakan modal untuk keperluan pembangunan dan ikut serta membantu rakyat dalam berhemat dan menabung dengan menyediakan tempat yang dekat, aman dan mudah untuk menyimpan uang.

Sasaran BPR yaitu untuk melayani kebutuhan para nelayan, petani, peternak, pedagang, pegawai dan pensiunan karena sasaran tersebut belum terpenuhi oleh bank umum dan lebih mewujudkan keseimbangan pelayanan perbankan, keadilan dalam kesempatan untuk berusaha, pemerataan penghasilan agar mereka tidak jatuh ke tangan para rentenir.

\section{Pengertian Tabungan}

Tabungan (saving deposit) merupakan jenis simpanan yang populer dikalangan masyarakat umum dari masyarakat kota sampai perdesaan. Menurut Undang-Undang Perbankan No.10 tahun 1998 pasal 1(9) Tabungan merupakan simpanan yang penarikannya hanya dapat ditarik melalui syarat yang telah disepakati, namun tidak dapat ditarik dengan cek, bilyet giro, atau alat sejenis lainnya. SedangkanTabungan adalah simpanan pihak ketiga pada bank yang penarikannya hanya dapat dilakukan sesuai dengan syarat yang telah disepakati oleh kedua piak, tapi tidak dapat ditarik dengan cek, bilyet giro dan atau alat lainnya Hejazziey, (2009).Tabungan merupakan bagian dari pendapatan yang disisihkan atau pendapatan yang tidakdikonsumsi, menjadi disimpan yang akan digunakan di masa yang akan datang (Pricilia I. Kasiang, Vekie Rumate 2018).

Dari pendapat diatas maka dapat disimpulkan bahwa pengertian tabungan adalah simpanan pihak ketiga pada bank yang penarikannya bisa dilakukan kapan saja sesuai dengan kesepakatan antara pihak nasabah dan pihak bank.

\section{Minat Menabung Nasabah}

Menurut Ensiklopedia Indonesia istilah minat dalam bahasa Inggris merupakan interest yang artinya perhatian, yakni kecenderungan dalam bertingkah laku secara teratur terhadap objek, kegiatan atau pengalaman. Menurut Anwar, (2001: 281) minat adalah perhatian kesukaan atau kecenderungan hati terhadap suatu hal (Maesaroh, 1970). Dari pengertian tersebut dapat disimpulkan minat adalah keinginan yang timbul dari diri sendiri tanpa adanya unsur paksaan dalam mencapai suatu tujuan tertentu.

Dalam dunia perbankan yang dimaksud dengan konsumen atau pelanggan adalah nasabah. Menurut Undang-undang No. 10 tahun 1998 tentang Perbankan pasal 1 “ Nasabah adalah pelanggan yang menggunakan jasa bank sedangkan nasabah penyimpan adalah nasabah yang menyimpan dananya dibank dalam bentuk simpanan sesuai perjanjian bank dengan nasabah yang bersangkutan Marlius, (2018)". 
Dari uraian diatas dapat disimpulkan bahwa minat menabung nasabah adalah tekad yang berasal dari diri nasabah dalam memanfaatkan produk atau jasa bank atau melakukan penyimpanan dana dengan tujuan tertentu

\section{Pemasaran (Marketing)}

Pemasaran adalah proses sosial yang didalamnya terdapat individu dan kelompok untuk mecapai apa yang mereka perlukan dengan menciptakan, menawarkan dan bebas melakukan pertukaran produk yang bernilai dengan pihak yang bersangkutan Basuki, (2019). Pemasaran dapat diartikan sebagai suatu proses sosial dan manajerial dari individu atau kelompok pembeli dalam memenuhikebutuhan dan keinginan melalui penciptaan, penawaran, pertukaran produk yang bernilai dengan seseorang atau kelompok Faizin, (2017) Melakukan pemasaran produk dan pelayanan bank adalah bagian terpenting dalam kegiatan usaha bank, hal ini menjadi bagian utama dalam meningkatkan keuntungan atau pendapatan pada bank tersebut, karena semakin banyak masyarakat yang berminat dengan produk yang ditawarkan tentunya akan menambah jumlah income perusahaan yang lebih besar. Karena hal ini sangat penting maka bagian marketing bank harus mengetahui dan menguasai strategi yang tepat dalam pemasaran bank untuk menarik minat calon nasabah. Strategi pemasaran bank biasanya didasari dengan 4 hal terpenting untuk mendukung maksimalnya strategi yang dilakukan. Hal-hal yang dimaksud adalah sebagai berikut :

\section{a. Produk (Product)}

Produk adalah segala sesuatu yang ditawarkan produsen untuk diperhatikan, diminta, dicari, dibeli, digunakan atau dikonsumsi pasar untuk memenuhi kebutuhan atau keinginan pasarMarlius, (2018). Oleh karena itu, dalam mempertahankan dan meningkatkan penjualan dan share pasarnya setiap bank harus melakukan usaha untuk menyempurnakan dan menjadikan perubahan produk ke arah yang lebih baik, agardapat memberikan daya guna dan daya pemuasan serta daya tarik yang lebih besar. Strategi produk ini menetapkan cara dan penyediaan produk yang tepat bagi pasar, sehingga dapat memuaskan para pelanggannya dan dapat meningkatkan keuntungan bagi pihak bank dalam jangka panjang, dengan cara meningkatkan penjualan dan peningkatan share pasar. Tujuan utama dari strategi produk adalah untuk mencapai sasaran pasar yang diinginkan sehingga dapat meningkatkan kemampuan dalam bersaing atau cara untuk mengatasi persaingan.

b. Harga (Price)

Agar dapat sukses dalam memasarkan produk atau jasa, setiap perusahaan harus menetapkan harga secara tepat. Harga merupakan satusatunya unsur bauran pemasaran yang menghasilkan pendapatan bagi perusahaan, sedangkan ketiga unsur lainnya yaitu produk, distribusi, dan promosi yang menyebabkan munculnya biaya (pengeluaran), disamping itu harga adalah unsur bauran pemasaran yang sifatnya fleksibel, artinya bisa berubah secara cepat Nuryadin, (2007).

Keputusan bauran harga berhubungan dengan kebijakan strategi dan taktik, seperti tingkatan harga, struktur diskon, ketentuan pembayaran dan tingkat perbedaan harga di antara berbagai kelompok pelanggan. 
Tingkat harga yang diatur sesuai dengan kuantitas yang terjual, selain itu harga juga mempengaruhi biaya, karena kuantitas yang terjual berpengaruh pada biaya yang dihasilkan darikemampuan produksi. Oleh karena itu penetapan harga mempengaruhi penghasilan total dan biaya total. Maka harga sangat berperan penting pada setiap perusahaan khususnya dalam pemasaran. Dengan demikian bisa disimpulkan bahwa dengan tingkat harga tertentu, apabila manfaat yang dirasakan konsumen meningkat maka nilainya juga akan meningkat.

c. Saluran Distribusi (Place)

Menurut Marlius, (2018) menyatakan bahwa " saluran distribusi terdiri dari suatu lembaga yang melakukan segala kegiatan yang berfungsi untuk menyalurkan produk dari produsen ke konsumen". Dari definisi diatas dapat disimpulkan bahwa saluran distribusi suatu produk merupakan semua kegiatan atau fungsi untuk memindahkan produk yang disertai dengan hak kepemilikan dari produsen ke konsumen atau untuk pemakaian industri. Distribusi ini berhubungandengan kemudahan dalam mendapatkan produk di pasaran. Untuk mempermudah calon nasabah memperoleh suatu produk maka salah satu faktor yang mendukung tercapainya produk ke tangan nasabah yaitu Pemilihan lokasi yang strategis karena sangat mempengaruhi maksimalnya pemasaran dan sebuah bisnis atau usaha yang dijalankan. Karena semakin strategis lokasi yang dipilih maka semakin mudah calon nasabah untuk mengetahui produk yang dimiliki oleh suatu perbankan.

d. Promosi (Promotion)

Menurut Fauzi, (2015)Promosi merupakan suatu variabel dalam bauran pemasaran yang sangat penting dilakukan oleh perusahaan dalam memasarkan produk dan jasa. promosi adalah salah satu bagian dari bauran pemasaran yang besar perannya. Kegiatan promosi dilakukan bersamaan dengan rencana pemasaran secara keseluruhan, serta direncanakan untuk diarahkan dan dikendalikan dengan benar agar dapat berperan dalam meningkatkan penjualan produk. Dalam rangka menunjang tercapainya pemasaran yang dilakukan, maka perusahaan harus menetapkan dan menjalankan strategi promosi yang tepat. Kegiatan promosi ini dilakukan oleh suatu perusahaan untuk penggunaan kombinasi yang terdapat dari unsur atau peralatan promosi, yang mencerminkan pelaksanaan kebijakan promosi dari perusahaan. Kombinasi dari unsurunsur promosi ini dikenal sebagai acuan/bauran promosi (promotional mix) yang terdiri dari :

1) Advertensi, merupakan salah satu bentuk penyajian dan promosi dari gagasan barang atau jasa yang dibiayai oleh suatu sponsor tertentu yang sifatnyanon personal. Media yang digunakan dalam advertensi yaitu televisi, radio, majalah, dan surat kabar.

2) Personal selling, yang merupakan penyajian secara lisan dalam pembicaraan dengan seseorang atau kelompok kepada calon pembeli dengan tujuan supaya terealisasinya penjualan. 
3) Promosi penjualan (sales promotion), merupakan kegiatan pemasaran yang menjadi menunjang dalam pembelian produk oleh konsumen dan keefektifan agen seperti pemeran, pertunjukan, demonstrasi dan segala usaha penjualan yang tidak dilakukan secara teratur atau kontinyu.

4) Publisitas (publicity), merupakan usaha untuk menarik permintaan dari suatu produk secara non personal, baik berupa berita yang bersifat komersial tentang suatu produk dalam media tercetak atau tidak, ataupunhasildari wawancara yang kemudian disiarkan dalam media tersebut.

5) Pelayanan prima, adalah pelayanan terbaik yang dilakukan perusahaan dalam memenuhi kebutuhan dan harapan pelanggan, baik pelanggan didalam perusahaan maupun diluar perusahaan.

Dalam upaya meningkatkan minat nasabah menabung PT. BPR Samudera Painan melakukan Marketing sebagai berikut :

1. Produk (Product)

PT. BPR Samudera Painan memiliki lima jenis tabungan yaitu :

a. Tamara (Setoran awal Rp. 10.000,-) yaitu tabungan masyarakat umum, yang mana setiap masyarakat bisa menabung pada PT. BPR Samudera painan dengan setoran awal yang sangat minim dan suku bunga sebesar $3 \%$.

b. Tuna (Setoran awal Rp. 20.000,-) yaitu tabungan yang memberikan undian kepada nasabah bagi yang beruntung. Tabungan ini sangat menarik bagi nasabah karena selain mendapatkan keuntungan tabungan ini hanya ada di PT. BPR Samudera Painan dengan tingkat suku bunga sebesar 3\%.

c. Pelajar (Setoran awal Rp. 5.000,-) yaitu tabungan khusus siswa/i pelajar dari TK, SD, SMP, SMA yang ada di kota painan ataupun sekitarnya, sehingga bisa mempermudah para pelajar untuk menabung karena tabungan tersebut dijemput setiap hari kerja.

d. Qurban (Setoran awal Rp. 20.000,-) yaitu tabungan masyarakat yang digunakan untuk membeli hewan qurban dengan tingkat suku bunga sebesar 3\% per tahunnya, sehingga masyarakat lebih muda untuk membeli hewan qurban karena uang yang ditabung aman.

Untuk menarik minat nasabah menabung, PT. BPR Samudera Painan melakukan strategi dengan menyediakan berbagai macam jenis tabungan sesuai dengan keinginan dan kebutuhan nasabah dan kemudahan dalam membuka rekening tabungan baru seperti hanya menggunakan fotocopy KTP dan Kartu Kartu keluarga untuk. Strategi andalan PT. BPR Samudera Painan adalah dengan cara penjemputan tabungan di rumah atau di tempat usaha nasabah, sehingga setiap nasabah yang ingin menabung maka nasabah tidak perlu datang ke bank karena pihak bank yang melakukan pelayanan penjemputan langsung ke rumah atau tempat usaha nasabah yang ingin menabung.

2. Harga (Price)

Untuk melakukan strategi yang berkaitan dengan strategi harga pihak PT. BPR Samudera Painan memberikan keunggulan terhadap produk yang 
dimilikinya, seperti produk tabungan yang mana di setiap produk diberikan dengan setoran awal mulai dari Rp. 5000 sehingga nasabah merasa tidak terbebani saat menabung, selain itu suku bunga yang diberikan juga sangat minim yaitu sebesar 3\% pertahun.

3. Saluran Distribusi (Place)

Dalam pendistribusian produk atau jasa-jasa bank, perlu adanya lokasi kantor yang tepat serta didukung oleh pemasaran yang terpadu. PT. BPR Samudera Painan berlokasi di Jl. Trikora Kecamatan IV Jurai Kabupaten Pesisir Selatan. Lokasi tersebut berada di jalan menuju carocok painan, tempat ini cukup strategis karena terletak banyak orang yang telah mengetahui jalan tersebut, sehingga mudah dijangkau oleh masyarakat dan juga dekat dengan lokasi usaha masyarakat yaitu pasar, pemukiman padat penduduk dan sekolah untuk tabungan para pelajar. Sehingga memberi peluang yang besar untuk PT. BPR Samudera Painan dalam meningkatkan jumlah nasabah.

4. Promosi (Promotion)

Promosi merupakan cara yang paling ampuh untuk memperkenalkan produk yang dimiliki oleh PT. BPR Samudera Painan kepada calon nasabah, melakukan promosi tidak hanya sekedar memperkenalkan produk tetapi juga menarik minat calon nasabah agar jumlah nasabah di PT. BPR Samudera Painan semakin meningkat. Bentuk promosi yang dilakukan yaitu dengan turun kelapangan secara langsung kelapangan untuk mempromosikan produk yang dimiliki pada PT. BPR Samudera Painan.Jenis promosi yang dilakukan pada PT. BPR Samudera Painan yaitu :

a. Periklanan (Advertising) iklan adalah salah satu sarana promosi yang dilakukan oleh PT. BPR Samudera Painan yang bertujuan untuk menginformasikan jenis produk dan tabungan dimiliki oleh bank tersebut. Informasi yang diberikan yaitu manfaat produk, harga, keuntungan serta keunggulan pada setiap produk. Tujuan promosi dengan iklan yaitu berusaha untuk menarik perhatian calon nasabah dan mempengaruhi calon nasabah agar tertarik dengan produk yang dimiliki.

Penggunaan promosi dengan iklan yang dilakukan oleh PT. BPR Samudera Painan yaitu :

1) Pencetakan brosur, pencetakan brosur ini berisikan produk dan jasa yang dimiliki oleh PT. BPR Samudera Painan yang kemudian disebarkan kepada masyarakat banyak. Penyebaran brosur ini diharapkan dapat menarik minat calon nasabah

2) Pemasangan spanduk di tiap-tiap kantor kas, pemasangan spanduk di pasang di tempat yang strategis dan banyak dilihat oleh masyarakat seperti di depan kantor atau di pinggir jalan raya.

3) Membagikan kalender, PT. BPR Samudera Painan membagikan kalender kepada calon nasabah yang berisikan produk dan jasa yang ditawarkan serta foto kegiatan yang dilakukan di PT. BPR Samudera Painan. Kalender ini dibagikan secara langsung oleh 
karyawan saat penjemputan tabungan kerumah atau ke tempat usaha nasabah.

4) Pemasangan iklan pada siaran radio, iklan ini dilakukan di Painan Radio, upaya ini dilakukan untuk memperkenalkan produk dan fasilitas kredit yang dimiliki oleh PT. BPR Samudera Painan kepada masyarakat

b. Penjualan pribadi (personal selling)merupakan promosi yang dilakukan oleh PT. BPR Samudera Painan melalui para karyawan bank dalam melayani serta ikut mempengaruhi nasabah dalam memperkenalkan produk dan fasilitas kreditnya kepada masyarakat. Salah satu promosi yang dilakukan oleh karyawan bank yaitu melakukan edukasi ke tempat-tempat umum seperti pasar, sekolah, dan ke majelis taklim untuk mempromosikan produk dan jasa yang dimiliki oleh PT. BPR Samudera Painan agar menarik minat masyarakat untuk menggunakan produk dan jasa pada bank tersebut.

c. Promosi Penjualan (sales promotion)kebijakan promosi penjualan dengan cara penarikan undian berhadiah untuk masyarakat yang menabung pada PT. BPR Samudera Painan dengan memberikan hadiah, seperti peralatan yang dibutuhkan dalam rumah tangga dan peralatan alat tulis untuk tabungan para pelajar. Promosi penjualan ini bertujuan untuk menyadarkan para nasabah tentang adanya keuntungan yang diperoleh atas produk dan jasa yang ditawarkan serta mendorong nasabah untuk meningkatkan penggunaan produk bank.

d. Publisitas (Publicity) promosi yang dilakukan oleh PT. BPR Samudera Painan dengan menggunakan sponsor saat mengadakan acara tahunan seperti memperingati hari-hari besar dan acara memperingati hari ulang tahun PT. BPR Samudera Painan. Kegiatan ini bertujuan agar nasabah mengenal lebih dekat dan meningkatkan pamor PT. BPR Samudera Painan dimata para nasabahnya.

e. Pelayanan Primapada PT. BPR Samudera Painan pelayanan prima merupakan pelayanan yang dilakukan dalam melayani nasabah semaksimal mungkin sehingga nasabah merasa puas dan nyaman. Salah satu contoh pelayanan yang dilakukan ketika nasabah memasuki bank, security akan menyapa dan menanyakan apa yang dibutuhkan nasabah sehingga nasabah tidak kebingungan dengan apa yang harus ia lakukan. Semua karyawan pada PT. BPR Samudera Painan selalu bersikap ramah saat nasabah berkunjung hal ini bertujuan agar nasabah merasa nyaman.

\section{SIMPULAN}

Berdasarkan hasil penelitian pada bab sebelumnya dapat disimpulkan upaya yang dilakukan PT. BPR Samudera Painan dalam meningkatkan minat nasabah menabung sebagai berikut :

1. Untuk menarik minat nasabah menabung PT. BPR Samudera Painan melakukan marketing mix mulai dari menyediakan produk tabungan sesuai dengan kebutuhan masyarakat, syarat-syarat yang simpel dalam untuk 
membuka rekening tabungan baru, menghilangkan biaya administrasi, lokasi yang strategis dan melakukan promosi ke masyarakat dengan membagikan brosur atau kalender serta melakukan edukasi ke sekolah dan majelis taklim

2. Dalam mempertahankan loyalitas nasabah PT. BPR Samudera Painan melakukan kegiatan membagikan hadiah dan melaksanakan acara tahunan seperti memperingati hari-hari besar dan memperingati hari ulang tahun PT. BPR Samudera Painan

3. Peningkatan pelayanan dengan cara menjemput tabungan nasabah di rumah, disekolah dan di tempat usaha nasabah.

\section{UCAPAN TERIMAKASIH}

Terima kasih penulis sampaikan kepada pimpinan PT. BPR Samudera painan dan seluruh karyawan/karyawati yang telah mengizinkan penulis dalam memperoleh informasi dan pengaambilan data.

\section{DAFTAR PUSTAKA}

Fernandes, Y. D., \& Marlius, D. (2018). Peranan Customer Service Dalam Meningkatkan Pelayanan Kepada Nasabah Pada PT. Bank Pembangunan Daerah Sumatera Barat Cabang Utama Padang. https://doi.org/10.31227/osf.io/wrh3p

Harry. G. 2014. "Analisis Faktor-Faktor Yang Mempengaruhi Kinerja Sistem Informasi Akuntansi Pada Bank Perkreditan Rakyat (BPR) Di Tanjung Pinang."

Hejazziey. 2009. "Pemberdayaan Koperasi, Usaha Mikro, Kecil Dan Menengah

(UMKM) Melalui Lembaga Keuangan Syariah (LKS) Untuk Mengentaskan Kemiskinan Dan Pengurangan Pengangguran.” Al-Iqtishad: Jurnal Ilmu Ekonomi Syariah

Hidayat. R. 2009. Jurusan Teknik Industri, and Universitas Trunojoyo Madura "Pengaruh Kualitas Layanan, Kualitas Produk Dan Nilai Nasabah Terhadap Kepuasan Dan Loyalitas Nasabah Bank Mandiri.” Jurnal Manajemen Dan Kewirausahaan.

Hidayati, R. R., \& Marlius, D. (2018). Aktivitas Promosi Dalam Meningkatkan Dana Pihak Ketiga Pada PT. Bank Perkreditan Rakyat (BPR) Batang Kapas Pesisir Selatan. https://doi.org/10.31227/osf.io/8dgqn

Kasmir. 2014. Bank Dan Lembaga Keuangan Lainnya.

Marlius, D dan Fernandes, Y. 2018. "Peranan Customer Service Dalam Meningkatkan Pelayanan Kepada Nasabah Pada PT. Bank Pembangunan Daerah Sumatera Barat Cabang Utama Padang."

Marlius, D., \& Nurfazila, N. (2020). Aktivitas Pemasaran Tabungan Pada Pt. Bank Pembangunan Daerah Sumatera Barat Cabang Pembantu Tarusan. https://doi.org/10.31219/osf.io/fvqc7

Marlius, D. (2016). Pengaruh Bauran Pemasaran Jasa Terhadap Minat Nasabah Dalam Menabung Pada Bank Nagari Cabang Muaralabuh. https://doi.org/10.31227/osf.io/vdqgx 
Marlius, D. (2017). Keputusan Pembelian Berdasarkan Faktor Psikologis Dan Bauran Pemasaran Pada PT. Intercom Mobilindo Padang. Jurnal Pundi. Volume 1. No. 1. Hal. 57-66. https://doi.org/10.31575/jp.v1i1.9

Sondakh, C. 2015. "Kualitas Pelayanan, Citra Merek Dan Pengaruhnya Terhadap Kepuasan Nasabah Dan Loyalitas Nasabah Tabungan (Studi Pada Nasabah Taplus BNI Cabang Manado).” Jurnal Riset Bisnis Dan Manajemen

Susanti. F, Marlius, D, Kahirumi. S. (2021). Customer Satisfication Pada Pembelian Smartphone Samsung Dilihat Dari Trust In Brand, Brand Image Dan Word Of Mouth Di Sarana Smartphone Kota Solok. Jurnal Pundi. Volume 5. No. 1. Hal. 1-20. Sekolah Tinggi Ilmu Ekonomi KBP. Padang.

Widayati. R dan Winda M 2019. "Upaya Penanganan Kredit Bermasalah Pada Bank Nagari Cabang Utama Padang."

Widayati. R dan Rizki A. 2019. "Aktivitas Pemasaran Produk Simpanan PT. Bank Tabungan Negara (Persero)Tbk Kantor Cabang Padang.”

Widayati. R dan Meliza E. 2019. "Aktivitas Pemberian Kredit Usaha Pada Pt. Bank Perkreditan Rakyat Batang Kapas."

"Undang-Undang RI No. 10 Tahun 1998 Tentang Perubahan Atas UU No. 7 Tahun 1992 Tentang Perbankan. Jakarta.” 